हो

\title{
MERANIE PRIESTOROVEJ DOSTUPNOSTI PÔŠT NA ÚZEMÍ MESTA BRATISLAVA POMOCOU PERCEPČNÝCH MIER DOSTUPNOSTI (KVALITATÍVNY PRÍSTUP)
}

\author{
František Križan", Ladislav Tolmáči ${ }^{* *}$
}

\section{Úvod}

Komunikácia prostredníctvom pošty si aj v súčasnom globalizovanom svete stále zachováva významné postavenie. Potvrdzujú to aj kvantitatívne ukazovatele a štatistiky služieb Slovenskej pošty, a.s.

Podla Čorejovej [2, s. 25] pri hodnotení vplyvu rozvoja poštovej a telokomunikačnej infraštruktúry na ekonomickú úroveň, resp. rozvoj a výkonnost' rôznych regiónov a miest je vhodné využívat' praktické prístupy a meratel'né ukazovatele dostupnosti v priestore. Dostupnost' možno považovat' za významný faktor obslužnosti územia, ako aj za jedno z najdôležitejších kritérií kvality pre sektor služieb [6] ${ }^{1}$.

Čorejová [2, s. 26] charakterizuje poštové služby ako siet'ový systém, čím je zabezpečená možnost' všeobecne dostupnej komunikácie a jej služby sú poskytované na celom území štátu. Treba však podotknút', že lokalizáciu jednotlivých poštových prevádzok možno na najvyššej hierarchickej úrovni (v rámci SR) považovat' za silne heterogénnu [10]. Disparity v priestorovom rozložení poštových prevádzok možno identifikovat' aj na nižšej hierarchickej úrovni (v rámci mesta).

Hlavným ciel’om príspevku je zhodnotenie dostupnosti pôšt na územní mesta Bratislava v sieti mestskej hromadnej dopravy, cestnej sieti a sieti pre chodcov pomocou percepčných mier dostupnosti.

\section{Účelová charakteristika Bratislavy}

Bratislava patrí medzi polyfunkčné mestá so širokým zastúpením poštových služieb. Na území mesta sa nachádza $49^{2}$ pôšt (rok 2006), so zvýšenou koncentráciou v centre mesta (obr. 1). Lokalizácia pôšt nekorešponduje $\mathrm{s}$ hustotou zal'udnenia $\mathrm{v}$ jednotlivých mestských častiach, skôr zohl'adňuje denný migračný pohyb obyvatel'stva. Preto je viacero pôšt lokalizovaných v riedko osídlených oblastiach, avšak s dobre vyvinutými službami ako napr. nakúpné centrá a pod.

Analýza prebiehala na úrovni urbanistických obvodov (UO). Z celkového počtu 263 UO je až 46 UO (17,5 \%) neobývaných. Objektom výskumu bolo 131 UO, v ktorých žije 500 a viac obyvatel'ov. Analyzované UO predstavujú 49,8 \% všetkých UO, avšak žije v nich až $98,1 \%$ populácie mesta.

\footnotetext{
* Mgr. František Križan, Katedra regionálnej geografie, ochrany a plánovania krajiny, Prírodovedecká fakulta UK Bratislava, Mlynská dolina 84215 Bratislava, email: krizan@fns.uniba.sk

* doc. RNDr. Ladislav Tolmáči, PhD., Katedra regionálnej geografie, ochrany a plánovania krajiny, Prírodovedecká fakulta UK Bratislava, Mlynská dolina 84215 Bratislava, email: tolmaci@fns.uniba.sk

${ }^{1}$ Je však nutné poznamenat', že nie vo všetkých prípadoch ide o priestorovú dostupnost' vo všeobecnosti chápanú ako funkciu priestorovej separácie dvoch regiónov.

${ }^{2}$ Tri pošty sídlia na rovnakej adrese (Tomášikova 54 ), a preto boli analyzované ako jeden objekt.
} 
Dostupnost' bola meraná v cestnej sieti, sieti mestskej hromadnej dopravy (MHD) a sieti pre chodcov (obr. 2 a 3). Bratislavská MHD pozostáva z 3 transportných trakcií. Najväčší podiel na preprave pripadá autobusom, čomu zodpovedá aj rozmiestnenie zastávok pozdlíz celého katastra mesta. Treba poznamenat', že niektoré mestské časti (MČ) sú odkázané iba na tento druh dopravy (Petržalka, Devín, Vajnory a i.). Na druhom mieste v počte prepravených osôb sú električky. Ich najväčšia koncentrácia je v centre mesta odkial' úsečkovito vybiehajú kol'aje do niektorých MČ. Najmenej pasažierov prepravia trolejbusy. Ich najväčšia koncentrácia je taktiež v centre mesta a predstavujú významnú spojnicu medzi jednotlivými MČ.

\section{Metódy a dáta}

Meranie dostupnosti je interdisciplinárna problematika. Vo všeobecnosti možno miery dostupnosti (Dst) členit' na kvantitatívne a kvalitatívne. Kvantitatívne miery dostupnosti zastupujú široké spektrum mier dostupnosti $[1,3,5,7,11,12]$.

Za nevyhnutnú súčast' tzv. multi-kriteriálneho výskumu dostupnosti považujú Zhu a kol. [13] práve dotazníkový výskum. Skupinu kvalitatívnych mier dostupnosti zastupujú tzv. percepčné miery. Percepcie ako miery dostupnosti vyzdvihujú viacerí odborníci $[4,8,12]$. Percepčné miery dostupnosti možno považovat' za syntetizujúce miery dostupnosti [12]. V príspevku boli aplikované nasledovné percepčné miery dostupnosti (Dst):

Dst1. Dostupnost' uzla určená odhadom respondentov. Handy a Niemeier [4, s. 1176] tvrdia, že: „praktická definícia dostupnosti musí vychádzat' od samotných obyvatel'ov, skôr ako od výskumníkov a musí odrážat' tie prvky, ktoré sú pre nich najdôležitejšie." Definovanie tejto miery závisí od aplikovanej škály pre jednotlivé uzly v sieti.

Dst2. V tomto prípade bola dostupnost' meraná aj alternatívnym hodnotením dostupnosti daných zariadení respondentmi pomocou škály známok vychádzajúc zo školského systému klasifikácie ( 1 = najlepšia dostupnost' až 5 = najhoršia dostupnost').

Dáta o počte obyvatel'ov a rôznych demografických ukazovatel'och boli získané zo štatistických materiálov z cenzu z roku 2001. Dotazníkovým prieskumom sa podarilo zachytit' vzorku 5622 respondentov, ktorí tvoria 1,31 \% všetkých obyvatel'ov Bratislavy. Ženy predstavovali 53,2 \% respondentov a priemerný vek opýtaných bol 36,2 rokov. Najväčší počet respondentov $(58,5 \%)$ dosiahol stredoškolské vzdelanie a najmenší počet $(13,6 \%)$ mal doposial' najvyššie dosiahnuté vzdelanie základnú školu. Ukončené vysokoškolské vzdelanie bolo zaznamenané v prípade $27,9 \%$ respondentov. Upravený dotazník bol prístupný aj cez odkaz na diskusnom fóre webovej stránky Dopravného podniku. Rekognoskácia prebiehala v mesiacoch január až jún 2006.

Výstupom analýz sú mapy vytvorené v programe ArcGIS (9.1) v podobe kartogramov. Z kartografického hl'adiska by bolo vhodnejšie bodové znázornenie namiesto plošného [9], avšak vzhl'adom na názornejšie a prehl'adnejšie zobrazenie dostupnosti bola zvolená technika kartogramov.

\section{Analýza}

Obr. 4-9 a tab. 1 a 2 dokumentujú výsledky merania pre aplikované miery dostupnosti. V cestnej sieti bola pre Dst1 priemerná hodnota stanovená na 5,1 min. Najnižšia nameraná hodnota bola 1,3 min (UO Vstupný areál Slovnaft) a najvyššia 12,0 min (UO Vinárky). Najväčší podiel obvodov (56,5\%), ale aj obyvatel'ov (62,1\%) spadá do kategórie do 5,0 min (tab. 1). Okrem centrálne lokalizovaných UO v MČ Staré Mesto (11), Nové Mesto (10) a pod. sem patria aj UO z marginálnych MČ ako napr. Záhorská Bystrica, Devín, Devínska Nová Ves, Podunajské Biskupice (obr. 4).

V obvodoch zaradených do druhej najpočetnejšej kategórie (5,1 až 10,0 min) žije vyše $1 / 3$ obyvatel'ov mesta (tab. 1). Aj v tomto prípade možno identifikovat' centrálne položené 
obvody, ako aj obvody z okrajových MČ (Jarovce, Čunovo). Patria sem aj obvody, na ktorých území sa nachádza pošta (Jarovce).

Kategória 10,1 až 15,0 min zoskupuje 3 UO (2,3\%), z ktorých sa 1 UO nachádza v Petržalke (Kapitulské pole) a 2 UO v Starom Meste (Holý vrch a Vinárky). Celkovo tu žije niečo vyše 2000 obyvatel'ov mesta (0,5 \%). Marginalita a napojenost' iba na jednu dopravnú trakciu zodpovedajú za dané hodnoty miery dostupnosti v prípade týchto UO.

Respondenti nepercipujú dostupnost' nad 15,0 min v cestnej sieti zo žiadneho analyzovaného urbanistického obvodu.

Tab. 1. Vybrané charakteristiky pre Dst1 v analyzovaných sietiach.

\begin{tabular}{|l|r|r|r|r|r|r|}
\hline \multirow{2}{*}{ Kategória } & \multicolumn{2}{|c|}{ Cestná siet' } & \multicolumn{2}{c|}{ Siet' MHD } & \multicolumn{2}{c|}{ Siet' pre chodcov } \\
\cline { 2 - 7 } & \multicolumn{1}{|c|}{ PUO* } & PO** & PUO & PO & PUO & \multicolumn{1}{l|}{ PO } \\
\hline do 5,0 min & $56,5 \%$ & $62,1 \%$ & $5,3 \%$ & $2,0 \%$ & $1,5 \%$ & $0,3 \%$ \\
\hline 5,1 až 10,0 min & $41,2 \%$ & $35,4 \%$ & $74,8 \%$ & $84,9 \%$ & $19,8 \%$ & $22,1 \%$ \\
\hline 10,1 až 15,0 min & $2,3 \%$ & $0,5 \%$ & $16,0 \%$ & $9,7 \%$ & $46,6 \%$ & $49,4 \%$ \\
\hline nad 15,0 min & $0,0 \%$ & $0,0 \%$ & $3,8 \%$ & $1,5 \%$ & $32,1 \%$ & $26,4 \%$ \\
\hline
\end{tabular}

PUO - počet urbanistických obvodov, PO - počet obyvatel'ov.

*relatívny počet zo skúmaných urbanistických obvodov (131), **relatívny počet zo všetkých obyvatel'ov mesta (428 672).

V sieti MHD bola pre Dst1 priemerná hodnota stanovená na 14,2 min. Najnižšia nameraná hodnota bola 4,1 min (UO Záhorská Bystrica) a najvyššia 18,3 min (UO Kapitulské pole). Dostupnost' do 5,0 min percipuje iba 2,0\% obyvatel'ov mesta žijúcich v 7 UO (tab. 1).

Najpočetnejšiu kategóriu predstavuje kategória 5,1 až 10,0 min, kam spadá 74,8 \% UO a žije tu 84,9 \% obyvatel'ov. Ide o obvody takmer zo všetkých MČ, kde má táto kategória dominantné postavenie (okrem MČ Staré Mesto).

Kategória 10,1 až 15,0 min je druhou najpočetnejšou kategóriou. Patria sem najmä obvody zo Starého Mesta (8) a Nového Mesta (5). Ide o obvody, ktoré v rámci svojich MČ patria k marginálnym (obr. 6).

Najmenej početná je kategória nad 15,0 min, ktorú zastupujú takmer výlučne UO zo Starého Mesta. Patrí sem aj UO Kapitulské pole z Petržalky, ktorého obyvatelia percipujú dostupnost' pôšt v sieti MHD ako najhoršiu zo všetkých UO v meste.

V sieti pre chodcov bola pre Dst1 priemerná hodnota stanovená na 14,3 min. Najnižšia nameraná hodnota bola 1,3 min (UO Vstupný areál Slovnaft) a najvyššia 40,0 min (UO Vinárky). Dostupnost' pôšt do 5,0 min percipujú obyvatelia iba z 2 UO (Vstupný areál Slovnaft a Devín).

Takmer 1/5 obvodov sa zarad'uje do kategórie 5,1 až 10,0 min, kde žije 22,1\% obyvatel'ov mesta (tab. 1). Patria sem najmä obvody z východnej časti mesta, pričom Ružinov predstavuje MČ s najväčším počtom UO (7 UO).

Najviac početná je kategória 10,1 až 15,0 min, ku ktorej sa hlási takmer 1/2 populácie mesta. Do 15 min je podl'a percepcií respondentov pošta dostupná pre $71,8 \%$ obyvatel'ov Bratislavy.

Vyše 1/4 obyvatel'ov vníma dostupnost' pôšt' v sieti MHD nad 15,0 min. Ide zväčša o marginálne obvody v niektorých MČ (Petržalka, Rača, Devínska Nová Ves, Dúbravka), ako aj o obvody z centra mesta (Staré Mesto), ktoré sa svojou polohou radia k centrálnym obvodom, avšak svojou dostupnost'ou k marginálnym (obr. 8).

Pri aplikácii Dst2 bolo úlohou respondentov klasifikovat' dostupnost' pôšt na základe školského systému známkovania, pričom 1 = najlepšia (výborná) dostupnost' a 5 = najhoršia (nedostatočná) dostupnost'. Tab. 2 predstavuje priemerné hodnoty pre analyzované UO. 
V cestnej sieti bola pre Dst2 priemerná hodnota stanovená na známku 1,3. Najnižšia hodnota 1,0 bola udelená v prípade až 14 UO a najvyššia udelená známka mala hodnotu 2,3 (UO Kapitulské pole).

Dostupnost' pôšt v cestnej sieti ako výbornú (známka 1) klasifikovalo vyše 90 \% respondentov (tab. 2), ktorí žijú v 112 UO (85,5\%). Ostatní obyvatelia klasifikovali dostupnost' na priemernú známku 2. Vyskytli sa individuálne prípady aj menej priaznivo klasifikovanej dostupnosti, avšak horšia priemerná známka ako 2 nebola zaznamenaná (obr. 5).

Tab. 2. Vybrané charakteristiky pre Dst2 v analyzovaných sietiach.

\begin{tabular}{|l|r|r|r|r|r|r|}
\hline \multirow{2}{*}{ Kategória } & \multicolumn{2}{|c|}{ Cestná siet' } & \multicolumn{2}{c|}{ Siet' MHD } & \multicolumn{2}{c|}{ Siet' pre chodcov } \\
\cline { 2 - 7 } & \multicolumn{1}{|c|}{ PUO* } & \multicolumn{1}{|c|}{ PO** } & PUO & PO & PUO & \multicolumn{1}{l|}{ PO } \\
\hline 1 & $85,5 \%$ & $90,2 \%$ & $53,4 \%$ & $52,4 \%$ & $37,4 \%$ & $40,5 \%$ \\
\hline 2 & $14,5 \%$ & $7,9 \%$ & $44,3 \%$ & $44,1 \%$ & $55,0 \%$ & $54,6 \%$ \\
\hline 4 a 5 & $0,0 \%$ & $0,0 \%$ & $2,3 \%$ & $1,6 \%$ & $6,1 \%$ & $2,7 \%$ \\
\hline
\end{tabular}

PUO - počet urbanistických obvodov, PO - počet obyvatel'ov.

*relatívny počet zo skúmaných urbanistických obvodov (131), **relatívny počet zo všetkých obyvatel'ov mesta (428 672).

V sieti MHD bola pre Dst2 priemerná hodnota stanovená na známku 1,5. Najnižšia známka má hodnotu 1,0 (UO Komisárky) a najvyššia známka hodnotu 3,0 v prípade UO Hostinského sídlisko (Nové Mesto) a UO Pošeň-východ (Ružinov).

Ako výbornú klasifikovalo dostupnost' pôšt v sieti MHD vyše $1 / 2$ obyvatel'ov Bratislavy. Väčšiu koncentráciu obvodov z tejto kategórie možno pozorovat' $v$ okrajových častiach mesta (obr. 7). Obyvatelia daných UO sú zrejme zvyknutí cestovat' za službami do centra mesta, a preto aj dostupnost' pôšt percipujú pozitívne.

Početnú skupinu (44,3 \% UO a 44,1 \% obyvatel'ov) predstavuje aj kategória $\mathrm{s}$ priemernou známkou 2. Patria sem obvody $\mathrm{z}$ centrálnej a južnej časti mesta s výnimkou 1 UO z Rače a UO Vajnory.

Dostupnost' pôšt na priemernú známku 3 percipujú obyvatelia z 3 UO z MČ Nové Mesto, Staré Mesto a Ružinov, v ktorých žije 1,6 \% populácie mesta (takmer 7000 obyvatel'ov). Ani v prípade sieti MHD, obdobne ako v prípade cestnej sieti, nebola stanovená horšia priemerná známka ako 3.

V sieti pre chodcov bola pre Dst2 priemerná hodnota stanovená na známku 1,7. Najnižšia priemerná známka má hodnotu 1,0 (UO Devín) a najvyššia hodnotu 4,0 (UO Čunovo).

Početnú skupinu UO, ktorých obyvatelia percipujú dostupnost' pôšt v sieti pre chodcov na známku 1 (tab. 2), predstavujú obvody s nepravidelným priestorovým usporiadaním. Možno hovorit' o akomsi mozaikovitom rozložení obvodov na území všetkých MČ.

Ako chválitebnú klasifikovalo dostupnost' pôšt (v sieti pre chodcov) 54,6 \% obyvatel'ov mesta. Ide o obvody, v ktorých sa nachádza poštová prevádzka, resp. ktoré sú lokalizované v susedstve týchto obvodov (obr. 9).

V centre mesta v MČ Staré Mesto možno identifikovat' až 6 UO, v ktorých respondenti percipujú dostupnost' pôšt na priemernú známku 3. Okrem toho sem patria aj Jarovce a UO Dopravná ulica v Rači. Títo respondenti predstavujú 2,7 \% obyvatel'ov mesta.

Najmenej priaznivo (horšia známka ako 3) klasifikovali dostupnost' respondenti z 2 UO. Najnepriaznivejšiu dostupnost' pôšt v sieti pre chodcov percipujú obyvatelia Čunova (známka 4,0). Obdobné výsledky boli zaznamenané v prípade UO Kapitulské pole (známka 3,9). Celkovo v týchto obvodoch žije 1562 obyvatel'ov. 


\section{Záver}

Dostupnost' poštových služieb predpisuje aj smernica EP č. 97/67/EC. Ako však poznamenáva Čorejová [2, s. 26] štandardy kvality Slovenskej pošty sú založené iba na kritériu rýchlosti, pričom nie sú uplatňované charakteristiky priestorovej dostupnosti.

Dostupnost' pôšt bola $\mathrm{v}$ tomto príspevku hodnotená 2 percepčnými mierami dostupnosti. V prípade prvej z nich bolo úlohou respondentov odhadnút' čas, za ktorý sú schopní dosiahnut' najbližšiu poštu. V druhom prípade mali ohodnotit' túto dostupnost' systémom školskej klasifikácie. Dostupnost' bola meraná v rámci 3 dopravných sietí. Boli nimi cestná siet', siet' mestskej hromadnej dopravy a siet' pre chodcov.

Z výsledkov analýz dostupnosti pôšt na území mesta Bratislava možno vyslovit' niekol'ko rezultátov:

- Vyše 97 \% obyvatel'ov Bratislavy percipuje dostupnost' pôšt v cestnej sieti do 10,0 min. V cestnej sieti (v komparácii so siet’ou MHD a sietou pre chodcov) sú respondenti schopní dosiahnut' niektorú z pôšt na území mesta v najkratšom čase (sumarizované hodnoty), čo potvrdzujú aj percepcie respondentov, z ktorých vyše $90 \%$ klasifikovalo dostupnost' na priemernú známku 1 a horšia známka ako 2 nebola stanovená.

- Najpočetnejšou kategóriou dostupnosti pôšt v sieti MHD je kategória 5,1 až 10,0 min. Respondenti vnímajú túto dostupnost' vel'mi pozitívne (priemerná známka 1,5).

- Vyše 1/5 obyvatel'ov percipuje dostupnost' pôšt v sieti pre chodcov nad 15,0 min, avšak vyše $95 \%$ respondentov klasifikovalo túto dostupnost' priemernou známkou 1, resp. 2.

- Obyvatelia zo žiadneho UO nepercipujú dostupnost' pôšt vo všetkých analyzovaných dopravných siet’ach ako nedostatočnú.

- Pri analýze vytvorenej databázy percepcií možno konštatovat', že rôzni jednotlivci heterogénne percipujú okolitý priestor a že nie sú rovnako ochotní cestovat' k daným zariadeniam. Dst2 predstavuje dôležitý až nevyhnutný doplnok Dst1, pretože krátku vzdialenost' k niektorému zariadeniu nemusia cestujúci vnímat' ako dobrú dostupnost'. Tento fakt zohl'adňuje práve Dst2.

V globále možno namerané hodnoty dostupnosti pre jednotlivé dopravné siete považovat' za uspokojivé. Analýza však poukázala na regióny s nedostatočnou priestorovou dostupnost'ou pôšt, čo by mohlo byt' odstránené obdobne ako navrhuje Čorejová [2] poštovňami.

V príspevku neboli analyzované nepriestorové aspekty problematiky dostupnosti, čo predstavuje námet na budúce smerovanie výskumu.

\section{Literatúra}

[1] BRUINSMA, F.R., RIETVELD, P.: The accessibility of European cities: theoretical framework and comparison of approaches. Environment and Planning A, 1998, 30, 499521.

[2] ČOREJOVÁ, T.: Pošty a telekomunikácie v riešenom území. Komunikácie, 2002, 1-2, 24-32.

[3] GEURS, K.T., VAN WEE, B.: Accessibility evaluation of land-use and transport strategies: review and research directions. Journal of Transport Geography, 2004, 12, 2 , 127-140.

[4] HANDY, S.L., NIEMEIER, D.A.: Measuring accessibility: an exploration of issues and alternatives. Environment and Planning A, 1997, 29, 7, 1175-1194.

[5] HORŇÁK, M.: Dostupnost' siete dial'níc a rýchlostných ciest v SR. Horizonty dopravy, 2005, 13, 1, 31-34.

[6] HRNČIAR, M.: Kvalita a jej meranie v službách dopravy, pôšt a telekomunikácií. Komunikácie, 2002, 1-2, 33-44. 
[7] KRIŽAN, F.: Meranie dostupnosti v geografii. In: Svatoňová, H. ed. Geografické aspekty středoevropského prostoru, Masarykova univerzita v Brne, Brno, 2005, 267287.

[8] KRIŽAN, F.: Intraurbánna dostupnost' vybratých zariadeni v Bratislave. Dizertačná práca, 2007, PRIF UK Bratislava.

[9] KRIŽAN, F., GURŇÁK, D.: Vybrané kartografické a grafické metódy znázorňovania dostupnosti. Acta Facultatis rerum naturalium Universitatis Comenianae, Geographica, 2008, 51, (v tlači).

[10] MATIS, P.: GIS prostriedky a metódy pre umiestnenie obslužných centier. Príspevok na konferencii GIS Ostrava 2005, 23.1.-26.1. 2005, ISSN 1213-2454.

[11] MICHNIAK, D.: Dostupnost' okresných miest na Slovensku. Geografický časopis, 2003, 55, 1, 21-39.

[12] TOLMÁČI, L.: Dostupnost' miest Slovenska. 1. vyd. MAPA Slovakia, Bratislava, 2002, str. 66, ISBN 80-89080-40-5.

[13] ZHU, X., LIU, S., YEOW, M.C.: Accessibility analysis for housing development in Singapore with GIS and multi-criteria analysis methods. Applied GIS, 2006, 2, 2, 13.113.12.

\section{Grantová podpora}

Príspevok vznikol za finančnej podpory grantovej úlohy VEGA č. 1/3064/06. 


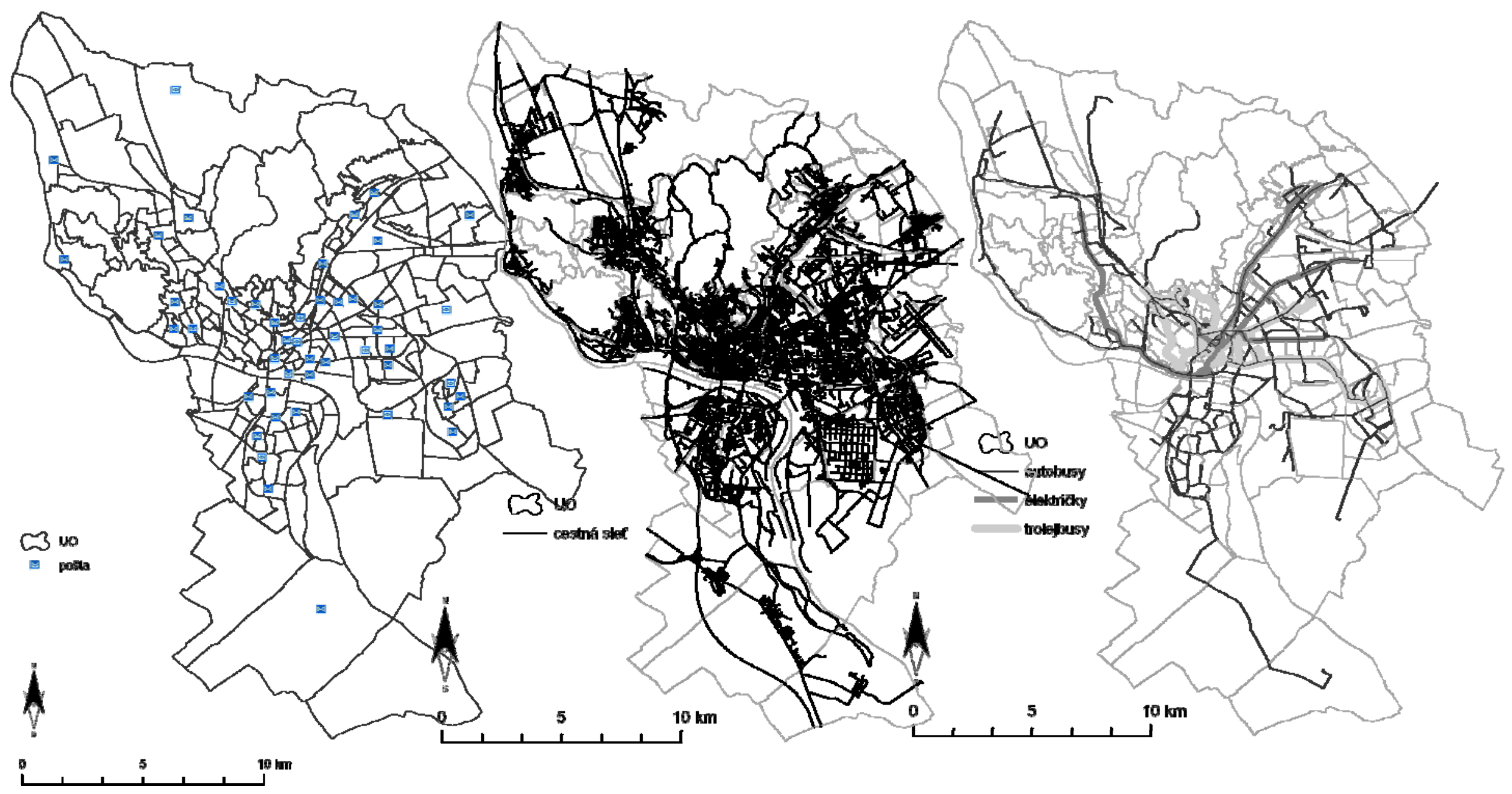




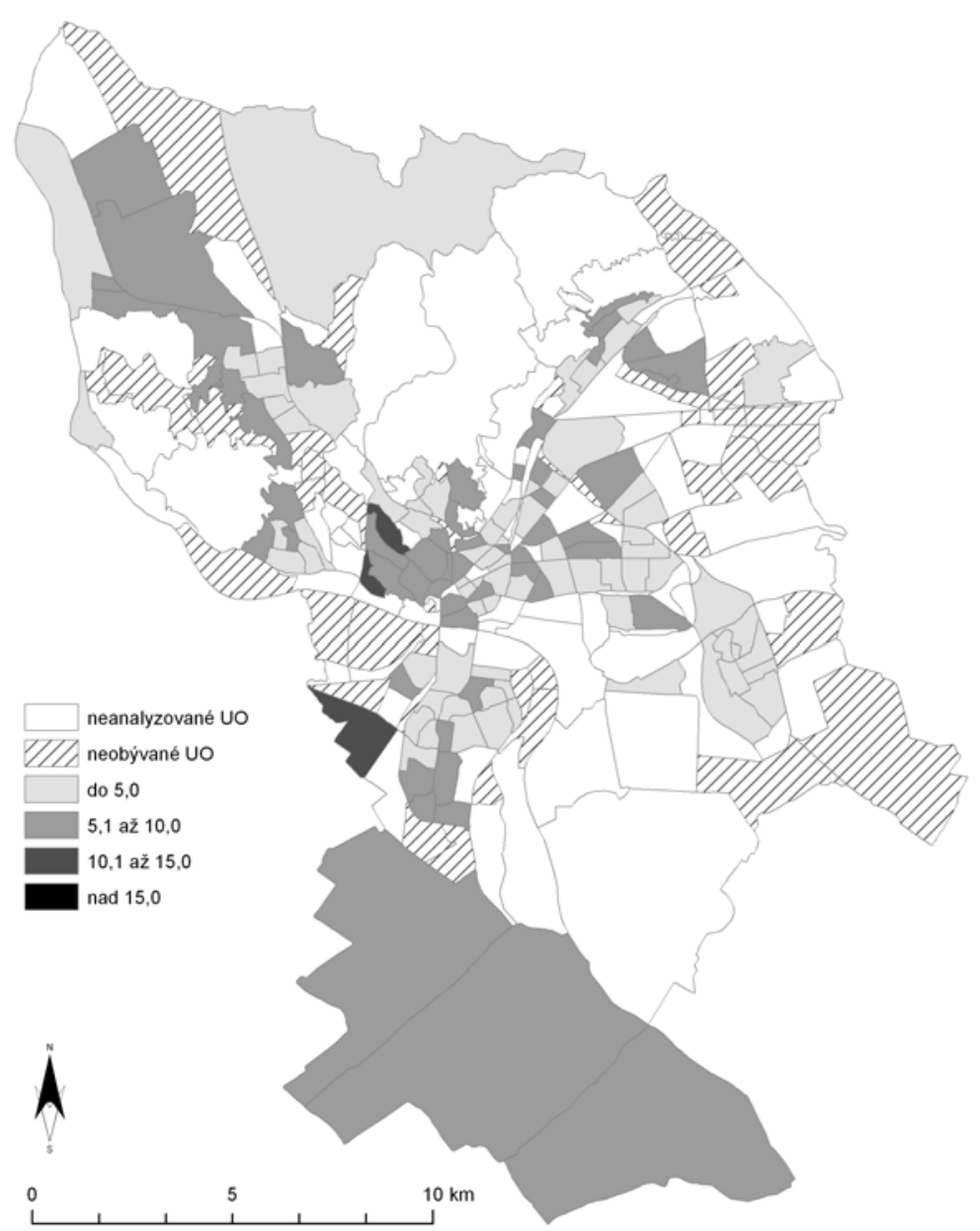

Obr. 4. Dostupnost' pôšt v cestnej sieti [min].

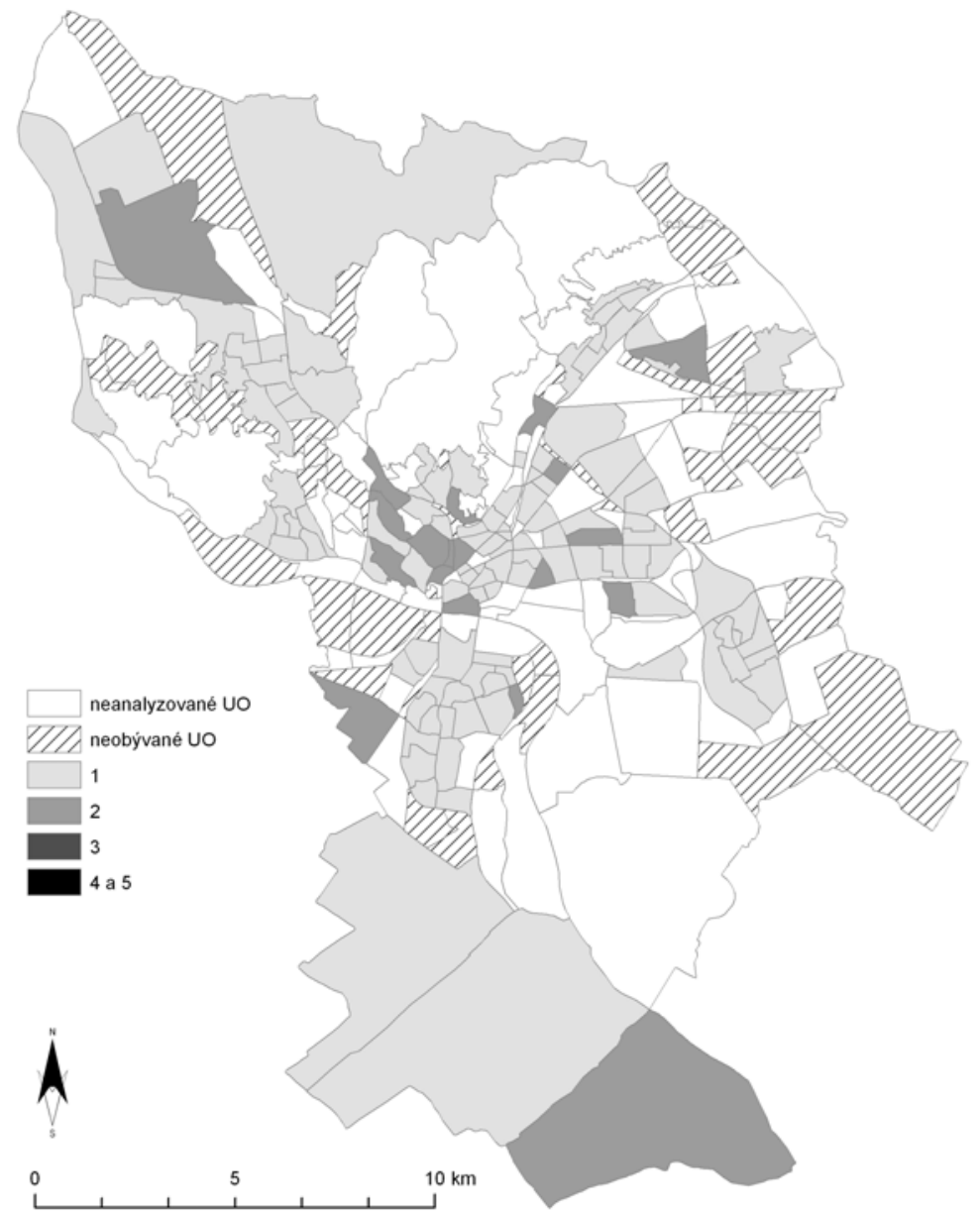

Obr. 5. Dostupnost' pôšt v cestnej sieti [známky]. 


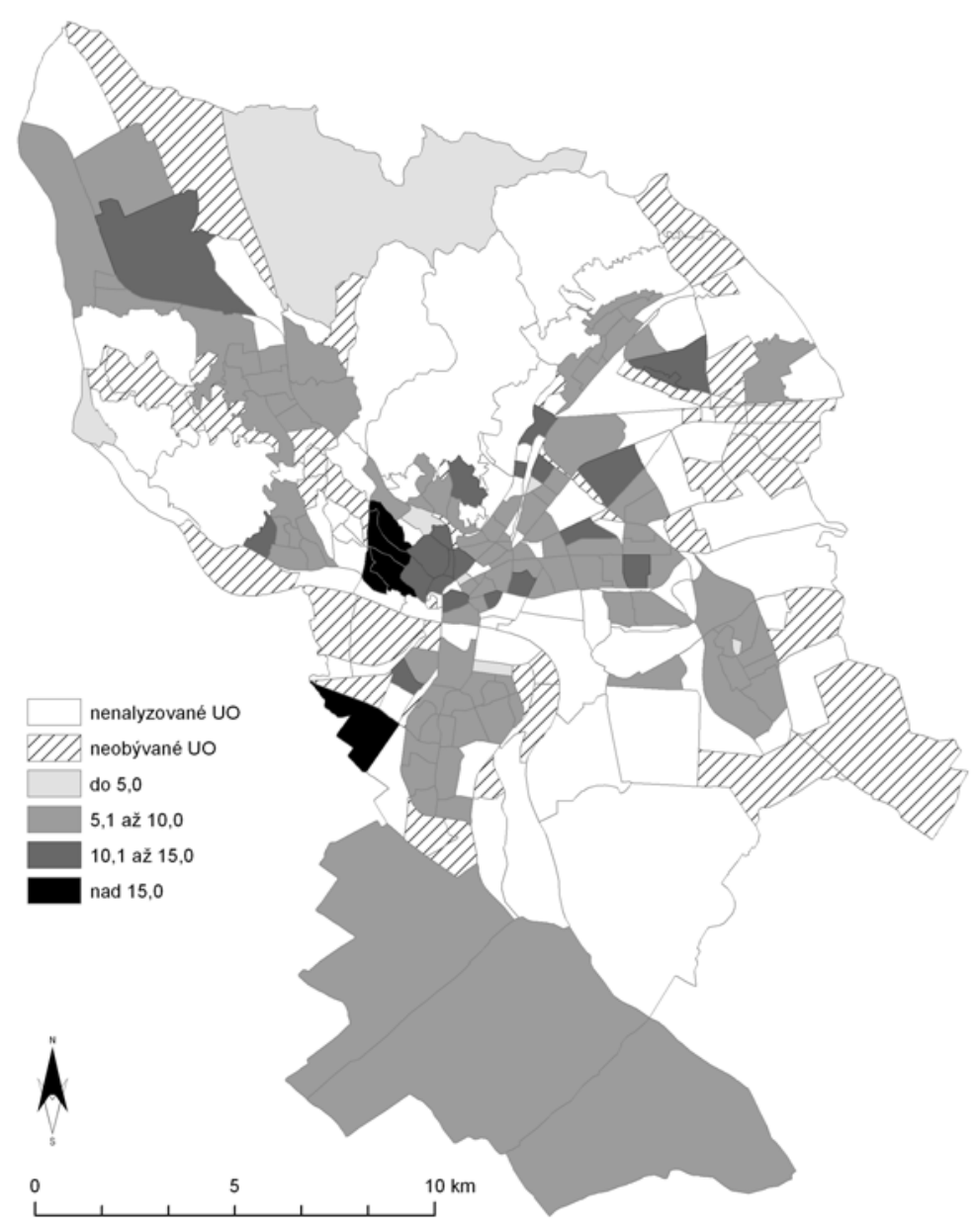

Obr. 6. Dostupnost' pôšt v sieti MHD [min].

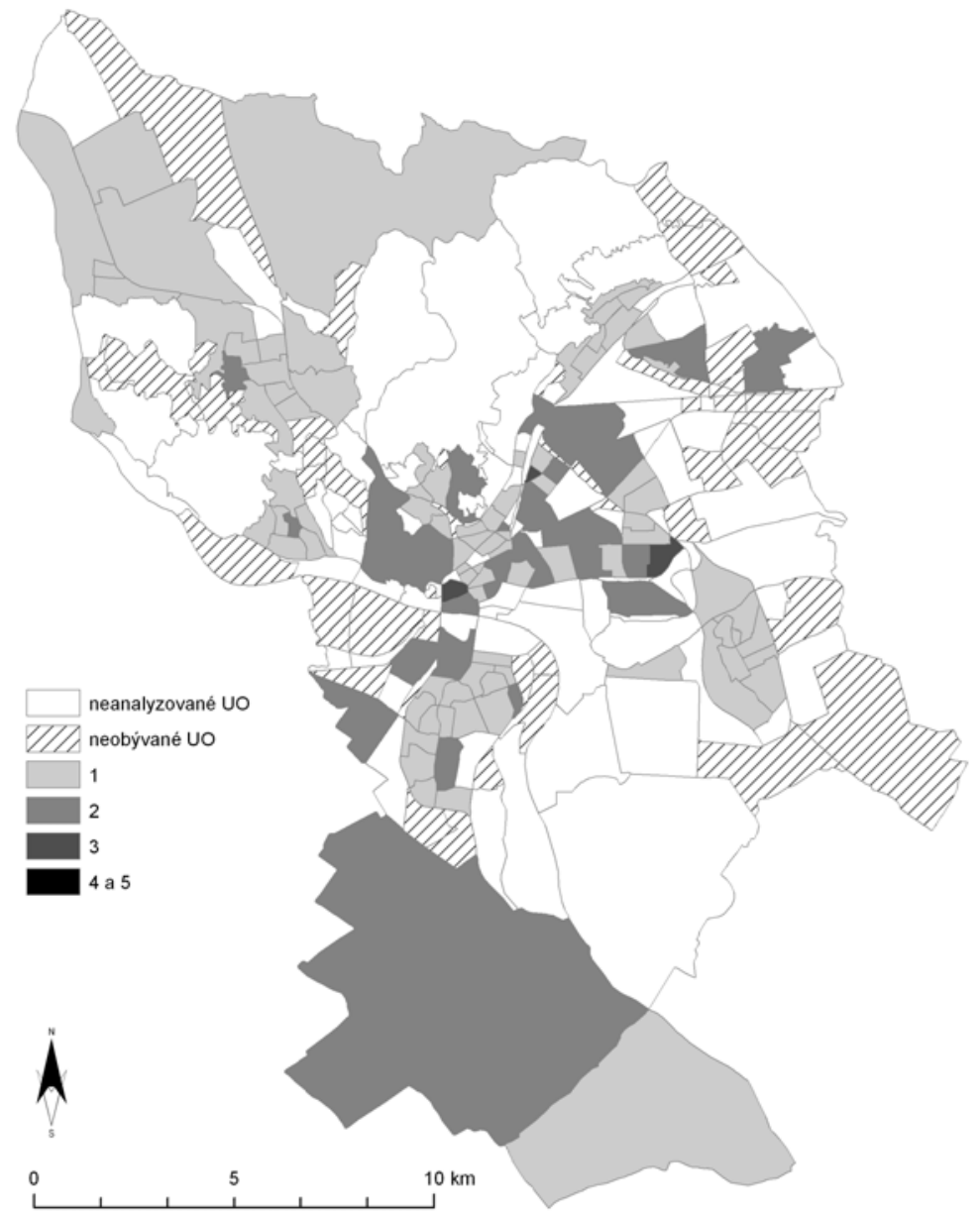

Obr. 7. Dostupnost' pôšt v sieti MHD [známky]. 


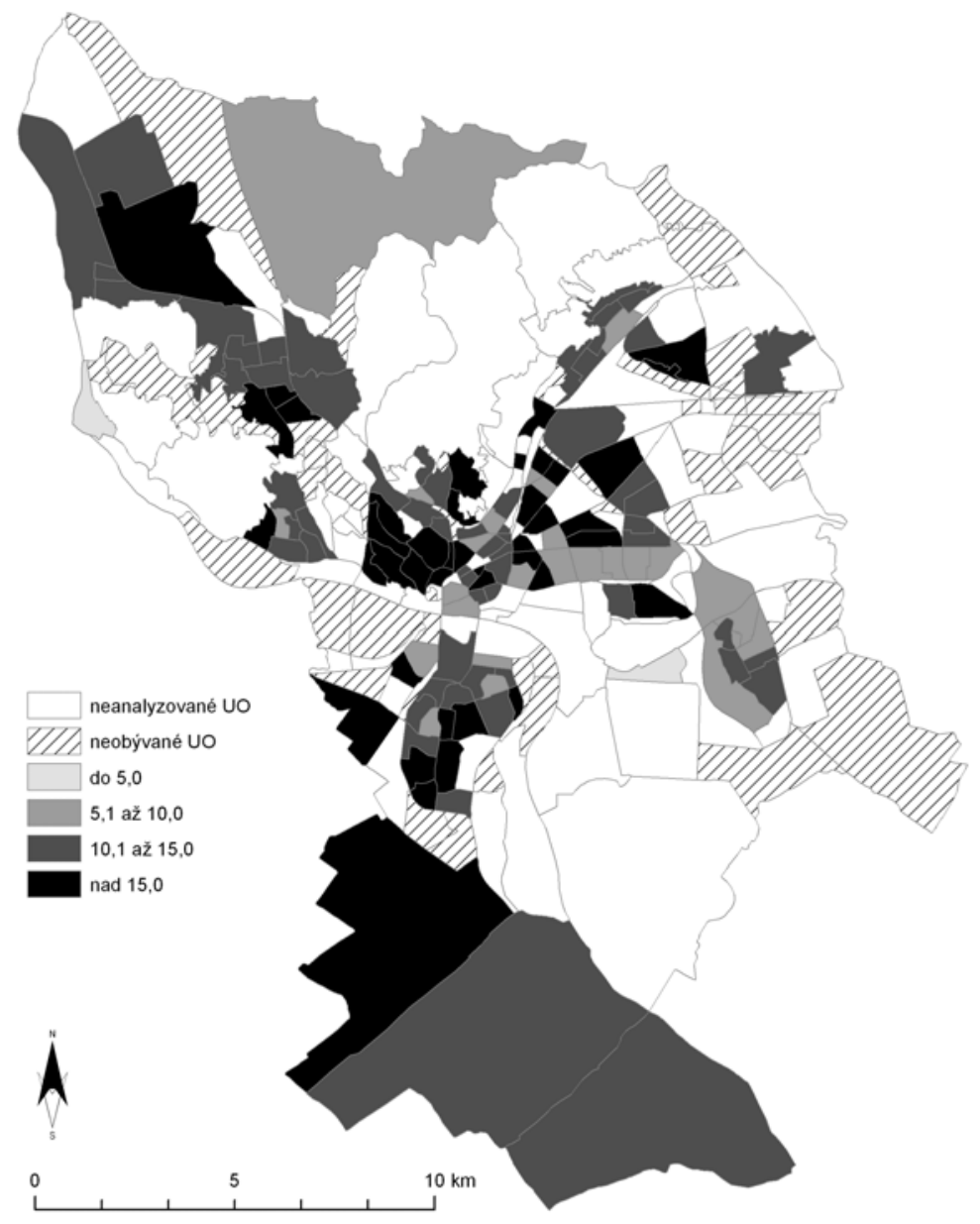

Obr. 8. Dostupnost' pôšt v sieti pre chodcov [min].

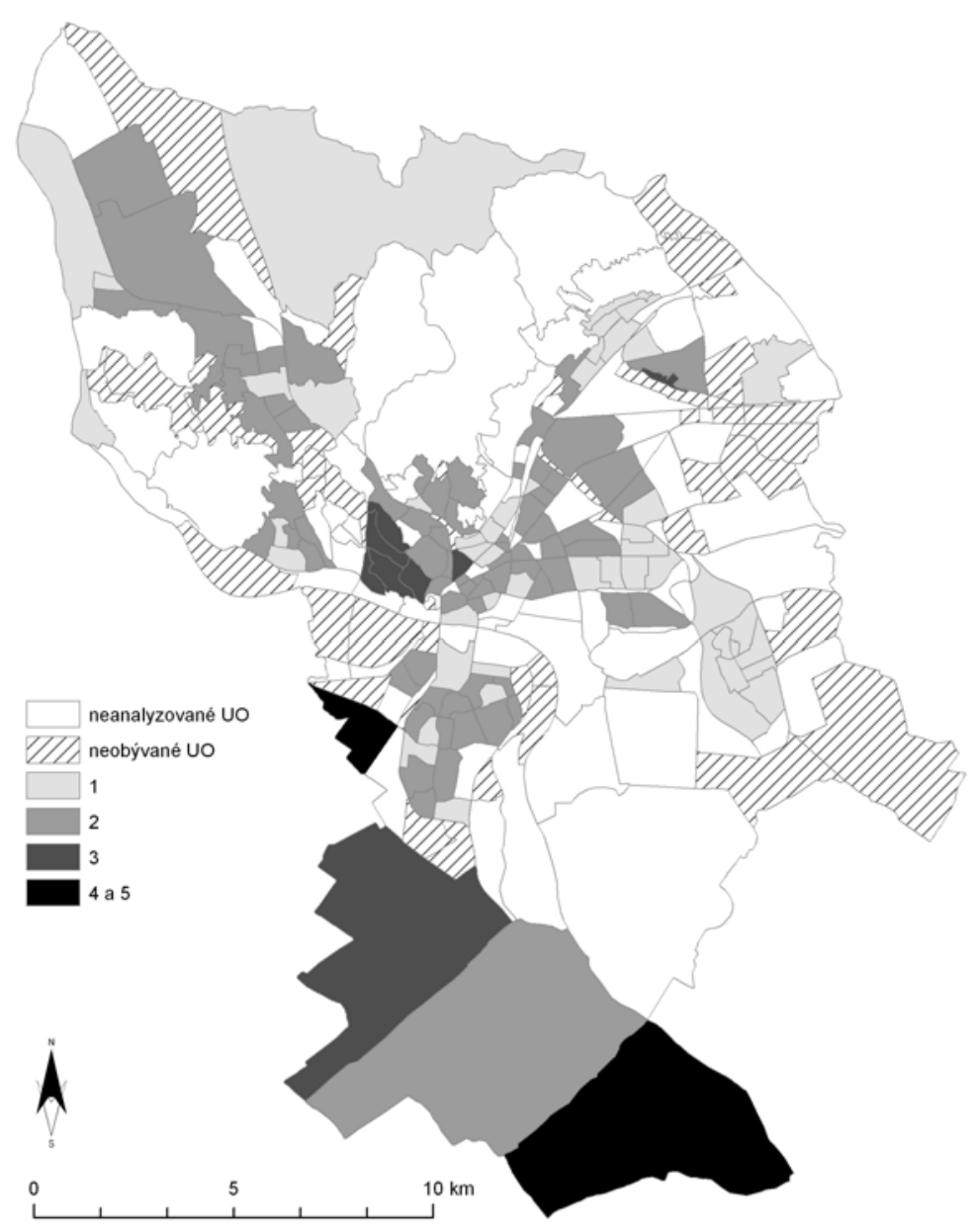

Obr. 9. Dostupnost' pôšt v sieti pre chodcov [známky]. 